Jakub Majewski

\author{
POLISH SPACE IN THE SYSTEM \\ OF THE EUROPEAN TRANSPORT CONNECTIONS
}

THE SPACE OF POLAND AND THE EUROPEAN SPACE

One could dare a proposition that Poland has virtually from the beginning of its existence had difficulties with the definition of its place in Europe. The fragment of the continent, which is occupied by our country, is in both physical and functional, as well as in the socio-economic sense, located neither in the centre nor in the periphery. It is not especially large, but its dimensions are sufficiently significant to make it non-negligible even in the general considerations on Europe. Thus, whether our country is perceived as a close and important one, or rather as significantly distant from the centre of the continent, depends first of all upon its individual features.

The dissonance between the reality, the geographical location, and the positioning defined by the perspective of one's consciousness, oftentimes results from the existence of barriers that are hard to overcome. They make places that are located, in fact, quite nearby, seen as distant. Nowadays, when the physical distances play a decreasing role, such areas start to be called far-off and hardly accessible. This, in turn, puts them aside in the network of connections and intensive contacts, and their weaker position is being taken advantage of by the areas, which are located - physically — farther off, but more easily accessible. A change of this situation requires overcoming of the "spatial friction" and the liquidation of the barriers making it impossible to use fully the assets related to location. A perfect example of such a situation is provided by the Nordic countries, and especially by Finland, which, in spite of a quite remote location, maintains much more intensive contacts with the centres of Europe than Poland does. ${ }^{1}$

Starting with the early 1990s Polish economy began to intensify its external connections. The transformation encompassing the change of the political and

1 An illustration for this phenomenon is supplied, for instance, by the intensity of air traffic in Europe. The DATAR map clearly shows that the flow of intensive contacts, originating from the Paris-London axis, omits Central-Eastern Europe, and directs itself towards the North of the continent (Kukliński, 1995). 
economic systems ended the era of the centrally planned economy, turning upside down the social and economic reality. The place of plans and directives, which had been until then deciding of the entire economic system, was taken by the free market and the capitalist mechanisms. Abolition of the "iron curtain" contributed to the increase of trade and intensified the search for new markets. The economy started slowly to inscribe itself into the setting of the global connections across the continent. On the other hand, the opening up of the new channels of economic and cultural expansion for the countries of the European Union contributed to the increase of spatial mobility of the societies and the rapid development of tourism.

During the recent years the space of Poland faced, therefore, again the problem of defining its place in Europe and inclusion in the network of global connections. The new, emerging economic system triggered off the process of opening up of the Polish space, necessary in order to avoid the danger of being pushed to the margin - to the role of periphery. Nowadays, namely, only an open space can secure the competitiveness of the economy, guaranteeing the free flow of innovation, goods, and services, or capital, forming, simultaneously, advantageous conditions for location.

One of the preconditions for the opening of the Polish space towards Europe is, beyond doubt, an effectively functioning network of transport and infrastructure connections that would, side by side with the telecommunication links, constitute the channels of innovation diffusion, exchange of ideas and goods. The former period established a lot of barriers across the connections between the Polish and European space, which will drag on for many years yet. Still, lack of a resolute action in these domains deepens the danger of pushing Poland into the peripheral zone, outside of the area of dynamic growth, along with all the political, economic, and social consequences of such a development. Although adaptation of the Polish technical infrastructure to the requirements and standards valid in the West of the continent is an enormous undertaking in both physical and financial terms, there is no alternative to it.

\section{THE CONCEPT OF INFRASTRUCTURAL NETWORKS}

The drive towards the integration and the improvement of functionality of the continent's space is in the focus of politics of the European communities since the signing of the Treaty of Rome. In spite of this, the effectiveness of the actual undertakings aimed at the unification and interlinking of the international transport networks has been and still is quite limited. A true-to-life basis for the process of integration of the European transport infrastructure arose only in the middle of the 1980s after the AGR, AGC and AGTC agreements had been signed (the European Agreement on Main International Traffic Arteries, the European Agreement on Main International Railways, and the European Agreement on Important International Combined Transport 
Lines and Related Installations). ${ }^{2}$ The process of integration of the transport means was additionally delayed by the structural transformations. While in the middle of the 1990s the road transport was entirely ruled by the market, the railways belonged still to these sectors of economy, which were virtually not affected by liberalisation and the changes. The monopolist enterprises, accustomed for years to the transport of goods through the territory of own country, formed the connection networks according to their needs. The obstacles to the introduction of the unified standards, encompassing the entire continent, were also constituted by the several rail gauges, the differing parameters of the traction systems, and also by the more than twenty signalling systems, valid nowadays in the unified Europe.

At the beginning of the 1990s, along with the political and economic changes in Central-Eastern Europe, Poland started to be included in the European programmes. In 1990 a special commission was established in Brussels, called "Group Transport 2000", which elaborated a report on the transport policy to date, and defined the foundations for shaping it in the changing political situation. It was then that the idea of the Trans-European Networks (TEN) appeared, encompassing, side by side with transport, also telecommunication and energy, in which the liberalisation of the market will take place at the earliest. ${ }^{3}$

Railroads became the primary area of the new reforms, with particular attention being paid to the commodity transport, remaining in the shade of the spectacular successes of the French or German fast passenger trains. It was noticed that the railways are a chance for job creation and the antidote for the increasing road congestion. Adoption of the proposal of the European Union was meant to stop the very disadvantageous decrease of the railway share in the transport of goods. According to the forecasts prepared for the European Commission, the continuation of this downward trend over the subsequent decade would end up with a paradoxical situation, in which congestion on the roads would have attained the intensity requiring a very radical action, while the alternative in the form of the railways would have disappeared in the meantime.

\section{INCLUSION OF POLAND INTO THE EUROPEAN SYSTEM OF CONNECTIONS}

In Poland, the process of integration of the transport network was taking place under the circumstances of the change of the model of economy at the beginning of the 1990s, which has uncovered the faults and shortcomings of

2 Side by side with the activities aiming at the integration of the transport network it was also assumed that they would, in parallel, contribute to the protection of the natural environment.

3 By virtue of assumptions, the access to the railway corridors would not be barred to various carriers, neither. 
Trans-European Transport Corridors in Poland

\begin{tabular}{|c|l|c|c|c|c|c|c|}
\hline \multicolumn{2}{|c|}{ Corridor } & \multicolumn{2}{c|}{ Length (km) } & \multicolumn{2}{c|}{ Costs (106 EUR) } & $\begin{array}{c}\text { Execution } \\
\text { time }\end{array}$ \\
\cline { 3 - 8 } & $\begin{array}{l}\text { rail- } \\
\text { ways }\end{array}$ & roads & $\begin{array}{l}\text { rail- } \\
\text { ways }\end{array}$ & roads & totals & (years) \\
\hline I & $\begin{array}{l}\text { Tallinn-Riga-Kaunas- } \\
\text { Białystok-Warsaw (with } \\
\text { a road branching Riga- } \\
\text { Kaliningrad-Elblag-Gdańsk }\end{array}$ & 1000 & 1000 & 170 & 240 & 410 & 10 \\
\hline II & $\begin{array}{l}\text { Berlin-Warsaw-Minsk- } \\
\text { Moscow (same as the } \\
\text { designed motorway A2 } \\
\text { and E20 railway line) }\end{array}$ & 1830 & 1830 & 900 & 1810 & 2710 & 15 \\
\hline III & $\begin{array}{l}\text { Berlin-Wrocław-Katowice- } \\
\text { L'viv-Kyiv (same as the } \\
\text { designed A4 motorway } \\
\text { and the E30 railway line) }\end{array}$ & 1640 & 1640 & 1520 & 1890 & 3410 & 15 \\
\hline IV & $\begin{array}{l}\text { Gdańsk-Katowice-Żylina } \\
\text { (same as the designed A1 } \\
\text { motorway and E65 railway } \\
\text { line) }\end{array}$ & 805 & 715 & 1230 & 2070 & 3300 & 15 \\
\hline
\end{tabular}

Source: Suchorzewski W., 1997.

the transport system. On the one hand the gaps were made apparent in the system of infrastructure, which is unable of fulfilling the tasks formulated by the economy, while on the other hand it turned out that the same infrastructure, which is lacking in some domains, is excessively developed in some other ones. The command-and-distribute system left an endowment of huge assets with low technical value, and with inadequate availability of infrastructure in definite domains.

The dramatic changes of that period were accompanied by the structural transformation and the restructuring of the entire sector. Transport volumes decreased, while their dominating share - similarly as in Western Europe - was taken over by the road transport. The latter, much more flexible, adapted more quickly to the new conditions, leaving behind the railways, inflexible, charged with excess employment and idle reserves, having trouble with finding its place in the new reality. Along with liberalisation of the economy international traffic increased, and the centre of gravity moved from the transport among the countries of the CMEA (Comecon) towards the countries of Western Europe. All these processes forced the change of orientation

4 It is envisaged already now that the axis Paris-Berlin-Warsaw-Moscow, supported by the backbone of the superfast railway, will be among the most rapidly developing corridors of Europe in the $21^{\text {st }}$ century. This constitutes an enormous opportunity for the space of western and central Poland (Kukliński, 1996). 
of Polish transport network and the necessity of looking at it in the perspective of the entirely new expectations of customers.

A precondition for the setting in motion of the true integration of Polish space with European space is constituted by the liquidation of the barriers separating them, resulting, in particular, from the discontinuity of the transport systems. At the same time it is necessary to stop, or even to reverse, the trends leading to marginalisation of the railway transport and the uncontrolled, anarchic growth of road transport, much quicker than the development of the road infrastructure, being maintained by the state. The conflict is being amplified by the fact that the railroad network has much better parameters, and its modernisation, as well as adaptation to the European standards, would cost but a fraction of the counterpart for the railroad network.

Side by side with the international agreements and the concepts encompassing the entire continent, which will bear influence on the shape of the road infrastructure of the country, the development of the infrastructural connections ought to be subject to the action of the endogenous factors, such as, for instance, the coincidence of the main directions and corridors of the domestic and international transport in Poland. It is also imperative to try to forecast how the implementation of the idea of the trans-European corridors and the creation of the growth belts based upon giant investments into infrastructure would contribute to polarisation of Polish space. The modern railways, motorways, or transmission lines will namely reach only a limited number of centres, leaving the other ones aside (Kukliński, 2000).

According to the forecasts, the dominating share of the international traffic will in the nearest future still be constituted by the end-destination traffic, ${ }^{5}$ while transit traffic in itself would continue to constitute a small portion of the overall transport flows, and would not justify the special, costly investments. Besides, the majority of long-distance hauls will be taken over by the air transport ${ }^{6}$ (Suchorzewski, 1997).

Hence the engine of changes directed towards the integration of the transport network and the shifts in the structure of hauls should be constituted - side by side with the process of integration of Poland with the European Union - by the autonomous transport policy of the state. This will make it possible to take advantage of the opportunities resulting from the location of the country, endowing Poland with a competitive edge in the new European space.

5 Directed largely to the border-adjacent regions.

6 Transit passage through Poland means covering the distance of at least $600 \mathrm{~km}$. If the western European trends extend to our region of the continent, then a vast majority of passengers would prefer to choose air transport. This will also be the case even if the fast railway line is built connecting Berlin with Warsaw. 


\section{REFERENCES}

Kukliński A., 1995, Europa Środkowa 2005 - scenariusze rozwoju [Central Europe 2005 - scenarios of the development; in Polish], Euroreg, Warszawa.

Kukliński A., 1996, The Grand Routes Linking Western, Central and Eastern Europe, Euroreg, Warszawa.

Kukliński A., Kołodziejski J., Markowski T., Dziemianowicz W., 2000, Globalizacja polskich metropolii [Globalisation of Polish metropolis; in Polish], Euroreg, Warszawa.

SuchorzewskiW., 1997, Miejsce Polski w europejskim systemie infrastruktury technicznej [The place of Poland in the European system of technical infrastructure; in Polish], Rewasz, Warszawa. 